\title{
Are Spanish TTOs Prepared to Innovation in a COVID Context?
}

\author{
Tamara Rodríguez-González ${ }^{1, *} *$, Mercedes Villanueva-Flores ${ }^{1}\left(\mathbb{D}\right.$, Mariluz Fernández-Alles ${ }^{1}(\mathbb{D}$ \\ and Mirta Díaz-Fernández ${ }^{2}$ (I) \\ 1 Business Organisation Department, University of Cadiz, 11002 Cadiz, Spain; \\ mercedes.villanueva@uca.es (M.V.-F.); mariluz.fernandez@uca.es (M.F.-A.) \\ 2 Business Organisation and Marketing Department, Pablo de Olavide University, 41013 Seville, Spain; \\ mdiafer@upo.es \\ * Correspondence: tamara.rodriguez@uca.es; Tel.: +34-600-29-48-86
}

check for

updates

Citation: Rodríguez-González, T.; Villanueva-Flores, M.;

Fernández-Alles, M.; Díaz-Fernández, M. Are Spanish TTOs Prepared to Innovation in a COVID Context? Sustainability 2021, 13, 8688. https://doi.org/10.3390/su13168688

Academic Editors: Fernando Almeida, Francisco Miranda González and Francisco I. Vega Gómez

Received: 14 May 2021

Accepted: 31 July 2021

Published: 4 August 2021

Publisher's Note: MDPI stays neutral with regard to jurisdictional claims in published maps and institutional affiliations.

Copyright: (c) 2021 by the authors. Licensee MDPI, Basel, Switzerland. This article is an open access article distributed under the terms and conditions of the Creative Commons Attribution (CC BY) license (https:/ / creativecommons.org/licenses/by/ $4.0 /)$.

\begin{abstract}
The analysis of the characteristics of Technology Transfer Offices (TTOs) is particularly important as they constitute mediating units in the relationship between the market and university research. They are responsible for the transfer and exploitation of knowledge arising in the university context. Previous studies have been inconclusive as to the importance that the size, professionalisation or age of TTOs might have on the transfer process. However, the need to explore new markets, recognise new opportunities and identify potential customers points to the importance of TTOs having a dual exploitative and exploratory orientation and an extensive relational network. More recent research in the literature, based on ambidexterity and network theory, points to the impact that these variables could have on change management and innovation in uncertain and changing environments, such as those faced by TTOs in the current pandemic context. Therefore, the aim of this paper is to analyse whether Spanish TTOs, due to their ambidextrous orientation at the organisational and individual level, and their relational network with academic and market actors, are prepared to promote innovation in a COVID-19 context. Based on a cluster analysis of 29 Spanish TTOs, our results show that just a few of the Spanish TTOs surveyed would be prepared, from the perspective of ambidexterity and their relational capital, to promote innovation in a COVID-19 context. In conclusion, Spanish TTOs and their employees should focus more on ambidexterity and building extensive relational capital so that, through mentoring, training, incubation or the provision of various resources, they can help academics take advantage of the innovation opportunities offered by the changing and uncertain environment.
\end{abstract}

Keywords: TTOs; ambidexterity; network theory; market actors; academic actors; cluster analysis

\section{Introduction}

The transfer of knowledge arising in universities and its commercial exploitation in the market, has gained considerable attention in recent years [1,2] as it is considered to be a source of innovation, competitiveness, new employment opportunities, as well as an economic and social development in the regions in which it operates [3-5]. Therefore, many universities have added this third mission to their strategic agenda so that research results can be known and used by industry [6-12]. For this purpose, they have established Technology Transfer Offices (TTOs) [4,13]. These units support the links between industry and research results, becoming key elements for innovation [14]. Across mentoring, incubation, training and networking, TTOs provide a number of critical resources for technology transfer $[15,16]$. These offices identify market opportunities, assist in the development of business plans, conduct market research and use their resources to build strong networks, reducing the barriers between academics and industry. They also encourage invention disclosures, manage patent grants, advise on appropriate commercialization strategies and assist academics in the commercialization process [15-18]. In the current context of the pandemic, where the innovative capacity of companies is considered crucial for their 
competitiveness $[19,20]$, TTOs must encourage investment in innovation through their relationships with industry. In this sense, TTOs play an important role, as they are seen [21] as catalysts for change and innovation, seeking to drive business strategies with a strong focus on innovation and internationalisation [22]. In this way, TTOs clearly act as intermediaries in innovation activities between universities and external actors, promoting the external commercialization of university research output [23]. The literature increasingly considers universities as drivers of innovation through these offices [3]. In this way, TTOs are units that drive innovation [24,25] for three main reasons. Firstly, with their advice, TTOs create academic spin-offs (ASOs) so that the investment made by these companies is reflected in the generation of employment, innovation and competitive advantages [26]. ASOs are considered an important driver in the renewal of industrial structures and a way to modernise industry [4]. Secondly, ASOs, created with the support of TTOs, are innovative because of the technological progress to which their commercialization process is linked [26]. They also solve the challenges related to climate and energy issues; sanitation; healthcare and welfare systems; the promotion of research-based professional practices; and the promotion of knowledge-based trade with industry [27]. Therefore, TTOs foster the innovation of the ASOs that are born out of them [5,28,29], Thirdly, TTOs, with their patenting management, encourage investments in innovation and disseminate knowledge through patent publications [23]. Consequently, TTOs enhance innovation through the performances they generate. Therefore, it can be concluded that innovation speed is influenced by the resources and competence of TTOs, as these resources speed up the process of matching university inventions and industrial commercialization [23] (p. 3).

Although the literature shows that TTOs contribute to fostering innovation, few studies have analysed the variables or characteristics of TTOs that could favour a context conducive to innovation. On the one hand, numerous studies have focused on analysing certain characteristics of TTOs, related to their success or efficiency. These have studied the impact of the age of these units; their size; and the professionalisation or experience of their employees, on their successes [4,16,21,30-35]. However, the results of some of these investigations are inconclusive. In this regard, [31] we can conclude that neither the size nor the human capital of a TTO seems to influence innovation performance, raising the question of what other characteristics may be important. Some work has focused on analysing the organisational structures of TTOs and how these structures affect the transfer of these units [36]. Other work has focused on the ambidexterity of universities [37-39] and on highlighting the potential importance of a dual exploitative and exploratory orientation in transfer activities. However, there are no studies on the ambidexterity of TTOs, the units responsible for this transfer. The literature on organisational ambidexterity has pointed out that this concept is paramount to the success of organisational innovation [40-44], as ambidextrous companies encourage the pursuit of new ideas. This organisational ambidexterity has been defined as the ability to develop structures and processes that allow TTOs to carry out activities of "exploitation" and "exploration" simultaneously, at the individual or organizational level [45].

These companies base their success on their ability to explore new opportunities, engage in quality improvement, reduce costs, or improve what they offer, to keep their existing customers satisfied [46]. In the context of universities, ambidexterity arises to alleviate tensions between the pursuit of research excellence and the commercialization of that research [37-39]. One way for achieving this ambidexterity lies in the construction of dual structures that allow conflicting demands to be managed simultaneously. Such dual structures could include the creation of a TTO within the university [37], but the mere existence of a TTO is not sufficient to achieve innovation outcomes. Therefore, new features of TTOs, such as ambidexterity, need to be analysed. On the other hand, the networking literature argues that relational capital is another essential factor for innovation success, as it has been considered in the literature as an enabler of innovation [47-49]. In the context of academic entrepreneurship, previous work highlights the importance of networks with academic and market actors [16,50-55] for ASOs created, with the advice 
of TTOs, to access critical resources [55]. Also, TTO networks that are made available to academics are considered important in the knowledge transfer process [56,57]. Thus, the TTOs use these networks and links to industry during the commercialization process [58].

Against this background, to be able to respond to the changes produced in the current pandemic context, ambidexterity, and the TTOs' relational networks, need to be decisive in boosting the innovation of these units. Therefore, the aim of this paper is to analyse whether Spanish TTOs, due to their ambidextrous orientation at the organisational and individual level, and their relational network with academic and market actors, are prepared to promote innovation in a COVID-19 context. The methodology used is based on a cluster analysis of 29 Spanish TTOs. The main finding shows that just a few of the Spanish TTOs surveyed would be prepared, from the perspective of ambidexterity and their relational capital, to promote innovation in a COVID-19 context.

The main added value of the paper is the contribution it makes to the literature on ambidexterity and networks, in the context of Spanish TTOs, which previous research has, so far, not focused on. Our results also have an important value in analysing the extent to which Spanish TTOs are prepared to promote innovation, by enriching previous research developed in the context of TTOs that failed to explain their transfer performance. In this sense, Spanish TTOs should work more on developing their ambidexterity, and on building a more developed relational network, to foster innovation in their performance, as in the case of the ASOs that arise from it. This paper also contributes to the literature the results of transfer offices, as well as ambidexterity and networks.

This paper is structured as follows: after the introduction, a literature review is presented, focusing on ambidexterity and relational capital. The different hypotheses are then presented, followed by the methodology and results. To conclude, there is a discussion of the results and the study's contributions and limitations.

\section{Theoretical Background}

Within the entrepreneurial ecosystem, TTOs play a key role. As actors that dynamise relations between academic and business contexts, they not only directly provide academic entrepreneurs with crucial resources and skills, but also facilitate their access to external actors that have these resources and skills $[59,60]$. Therefore, TTOs are units that, through different mechanisms, such as incubation, financing and consultancy, foster an entrepreneurial culture in universities. To this end, they conduct market research, use their resources to build strong networks, identify market opportunities and assist in the development of business plans, reducing the barriers between academics and industry $[17,18]$. Ultimately, they provide specific resources to academics such as: managerial resources; tangible technological resources (laboratories and equipment); and intangible technological resources (advice, testing, commercial resources, distribution channels, financial resources, knowledge and credibility) [15,16,32,61-68].

The relational networks provided for academics by TTOs, become a critical element for knowledge transfer [67]. Similarly, the literature on ambidexterity, both at the organisational level and in the context of universities, states that organisational ambidexterity fosters organisational innovation [37-39,41]. Thus, we believe that both characteristics of TTOs, ambidexterity and relational capital, must be considered for TTOs to be innovative and to adapt to the changes that the pandemic context presents.

\subsection{Ambidexterity of Technology Transfer Offices}

The literature on ambidexterity argues that successful companies need to be ambidextrous [69,70], as ambidexterity promotes organisational growth and adaptation [41]. Thus, with the main objective of companies being able to survive in the face of continuous environmental changes, ambidextrous organisations use their existing assets and capabilities and reconfigure them to address new opportunities [41]. Organisations must therefore exploit existing competencies and explore new ones; crucially, these two facets must be inseparable [71]. Furthermore, organisational ambidexterity is shown to be positively 
associated with improvements in innovation [40,72-80]. Empirical evidence suggests that ambidexterity generally has a positive effect on firm performance, demonstrating that, for long-term success, companies should consider establishing dual structures [81].

The literature on entrepreneurial universities argues that, although universities have increasingly oriented their strategic plans towards the development of activities, related to the third mission [82], they must be ambidextrous (i.e., they not only need to be aligned, efficient and exploit research-related activities, but also need to commercialise this research) [37,42]. In this context, the establishment of the dual structures, proposed by [81], would take place through the establishment of TTOs [37]. Therefore, based on the literature on organisational ambidexterity, the challenge of ambidexterity faced by organisations and universities also affects TTOs.

Considering the importance of ambidexterity for innovation; the scarce research on ambidexterity in the university context [37-39]; the lack of studies on the ambidexterity of TTOs; and the existence of studies with inconclusive results on the characteristics of TTOs that affect their efficiency and success $[16,17,30,32,83-85]$, the ambidexterity of TTOs needs to be considered.

Within ambidexterity, two types are analysed: the ambidextrous orientation of the TTOs and the individual ambidexterity of its employees. Firstly, ambidextrous orientation is defined as the ability of an organisation to adapt to changes in the environment and exploratory orientation, while simultaneously being aligned and efficient in responding to market demands and exploitative orientation [39]. Secondly, individual ambidexterity refers to the ability with which employees in organisations can simultaneously achieve both explorative and exploitative activities [86].

\subsubsection{Ambidextrous Orientation of the Technology Transfer Offices}

Given the claim of some authors [37-39] for the need to establish universities that are ambidextrous, and the lack of previous studies on the ambidexterity of TTOs, the concepts of organisational ambidexterity and the ambidexterity of universities must be extrapolated in the context of TTOs.

Inspired by the work of [46] on organisational ambidexterity, we propose that TTOs, with ambidextrous orientation, study the capacity of these units to exploit the services they offer (exploitative orientation), while simultaneously exploring new ideas and services to propose to academics and companies (exploratory orientation). Two clearly differentiated strategies to be implemented in the TTOs, are established. On the one hand, there is an exploitative orientation dedicated, among other activities, to improving quality, reducing costs and improving the reliability of the services offered to academics and companies by these offices. With this orientation, these TTOs also strive to make technological or marketing improvements to existing TTOs, in order to better adapt to the current environmental conditions and the needs of their customers. On the other hand, this exploratory orientation allows TTOs to be competent, responding proactively to changes in the context by searching for new innovations. It is a type of strategy mainly focused on the exploration of new ideas, the creation of innovative services, or the search for new markets for academics and companies at national and international levels. TTOs must strike a balance between both strategies, because if these units are mainly oriented towards exploration, they may lack the resources to sustain such efforts over long periods of time. This would result in TTOs not getting the returns on their knowledge: "an organisation that engages exclusively in exploration will ordinarily suffer from the fact that it never gains the returns on its knowledge" ([87], p. 105). Conversely, if a TTO primarily develops an exploitative orientation, its returns may be more proximate and predictable than a TTO that seeks exploration, although these are not necessarily sustainable, because they run the risk of obsolescence. In this way, the TTOs will be ineffective in adapting to major changes and, as a consequence, these offices "that engage exclusively in exploitation, will ordinarily suffer from obsolescence" [87] (p. 105). 
Thus, for TTOs to have an ambidextrous orientation, they must jointly pursue both strategies, i.e., building on existing competencies through exploitation, while developing new innovative capabilities through exploration.

Based on the above, for TTOs to be ready for innovation in a pandemic context, they must have an ambidextrous orientation, and the following is therefore hypothesised:

Hypothesis 1 (H1). Technology Transfer Offices are ambidextrous in orientation in a pandemic context.

However, and following [86], one cannot ignore the way in which the members of an organisation, in our case the employees of TTOs, can influence the ability of these units to achieve a balance between exploitation and exploration. This fact leads us to address the individual ambidexterity of these units.

\subsubsection{Individual Ambidexterity in the Technology Transfer Offices}

The literature on ambidexterity defines individual ambidexterity as a "behavioural orientation towards combining exploration and exploitation, related activities within a certain period of time" [88], so that "individuals engage in exploration while carrying on exploitation by allocating time and resources between the two different activities" [89] (p. 467). Activities related to individual ambidexterity have been widely recognised as beneficial to individuals, and empirical results have shown that this ambidexterity enriches employees' jobs, promotes their creativity, and thus their performance [88].

The concept of individual ambidexterity in an academic context is a very recent creation, so there are very few studies focusing on this issue and there are no studies dealing with individual ambidexterity in TTOs. In [39] (p. 9), individual ambidexterity is defined in an academic context as "the ability to which academic scientists can simultaneously achieve research publication and research commercialization at the individual level". With limited time availability and scarce resources, ambidexterity drives academics to maintain an optimal balance between research, commercial exploitation or transfer activities. An individual's ability to perform these often quite contradictory tasks is almost certainly linked with their desire to do so [90]. Motivation to pursue commercial products is not only a function of an individual's utility, but is also linked to the individual's perceptions of the compatibility of research commercialization with their professional career [37]. Thus, [39] conclude that: the greater the ability of university members to recognise the opportunity to exploit the results of their research, the greater the individual-level research ambidexterity in universities.

In the context of TTOs, as there are no studies focused on the analysis of this type of ambidexterity, we followed the suggestion of [69] (p. 81) in which states that "ambidextrous organisations need ambidextrous teams and managers", so we considered it necessary for TTOs to be made up of ambidextrous employees. Firstly, according to [86], an exploitative orientation of individuals would lead employees of TTOs to perform activities known to them, which require their previous accumulated experience. In this way, the staff of these units encourage academics, with whom these offices have a close relationship, to disclose their inventions [16]. Second, an exploratory orientation of TTO employees could guide them to seek out new academics to become involved in the development and creation of ASOs, explore new markets, identify new potential customers, or engage in new activities that require acquiring new skills or knowledge. In turn, this search for new markets and customers would contribute to the recognition of innovative business opportunities, which could be exploited through the creation and development of ASOs, as well as through patenting and licensing.

Based on the above, we concluded that for TTOs to be prepared for innovation in a pandemic context, their workers must be ambidextrous, and we hypothesised the following:

Hypothesis 2 (H2). Technology Transfer Offices are ambidextrous at the individual level in a pandemic context. 


\subsection{Relational Capital of the Technology Transfer Offices}

The networking literature starts from the premise that entrepreneurs who are immersed in a wide network of contacts have access to a wider range of resources [91-93].

Based on the literature on academic entrepreneurship [64,68,94-97], the relational networks of TTOs, as with those of ASOs, can be classified into networks with academic and market actors [58]. The relationships between TTOs and academic actors, such as with other universities, incubators and academics, allow access to mainly technological resources in the form of infrastructure; equipment and facilities; and information resources, such as academics' research and its transfer of results as patents. Relationships with market actors, such as investors (venture capital firms), government institutions, advisors, companies, customers and managers, or science and technology parks, become key elements for access to other financial, technological and managerial resources [15,16,32,61-68].

The literature analysing the relational capital of TTOs has shown that TTOs provide ASOs with a multitude of resources $[9,15,16,65,68]$, many of them coming from the relational network they have built up since their creation. Thus, TTOs' relational networks with market actors are crucial for identifying commercialization partners, funding sources and support, and aligning research with industry needs [5] to identify new opportunities for innovation. In this way, TTOs that have a developed relational network, both in academia and the market, can leverage the skills and roles of universities within society, enabling co-operation between academics, technology centres and ASOs [22]. TTOs must not only be able to create these relational networks, but be able to identify possible relationships that may arise between academia and the market in order for knowledge transfer to occur more effectively [16].

Participation in these networks would be beneficial for both parties; academics could increase their research (e.g., the number of publications or patents) and companies could improve their innovation capabilities [57]. These relationships could be instrumental in fostering innovation, as these resources could facilitate the recognition of opportunities, the development of attractive business plans, the commercial viability of inventions, or simply intermediation. Consequently, relational networks are paramount to the success of innovation, and networks are important factors to consider in the knowledge transfer process [16,57].

The literature highlights the different ways of establishing TTOs' relationships. On the one hand, conferences and exhibitions are critical activities in the establishment of relationships between the scientific community and industry. On the other hand, the mobility of people (in research centres and other universities, etc.), or the establishment of informal contacts, together constitute the relational networks necessary to accelerate the process of knowledge transfer [16,34]. The bidirectional nature of knowledge transfer means that interaction with companies makes it possible to carry out better academic research, insofar as it provides first-hand knowledge of the needs that the industry intends to satisfy, with the creation of specific knowledge or technology.

For academic entrepreneurs, TTOs therefore become key relational network providers for obtaining resources for the transfer, entrepreneurship, and development of their innovation. Therefore, for TTOs to foster innovation in a pandemic context, they must have developed relational capital, both at the academic and market level. We therefore propose the following hypothesis:

Hypothesis 3 (H3). Technology Transfer Offices have a developed relational network with academic and market actors in a pandemic context.

\section{Methodology}

Population, Sample and Measures

For data collection, a questionnaire was sent to the directors and two managers in each of the 70 TTOs at the Spanish universities in the TTO Network (RedTTO). The questionnaire, previously tested with the director of the TTO of the research team's university, aimed to 
identify whether the offices were ambidextrous and whether they had developed relational capital. For the process of sending and collecting the information, the directors of the TTOs were contacted by telephone; we obtained information from 29 TTOs $(41.42 \%$ response rate). Three questionnaires were sent to each office, to be completed by the director and managers. When different responses were obtained from the same TTO, the degree of similarity between the responses obtained from the same office, was analysed. The TTOs in our sample responded to the questionnaires at the time of the pandemic.

The measure of the ambidextrous orientation of TTOs was also based on previous research [46]. The measure consisted of 12 items, six to reflect the exploitative orientation and six to reflect the explorative orientation. An example of the first group of items described a TTO as a unit "committed to improving quality and reducing costs", whilst an example of an item within the second group described the TTO as a unit that "bases its success on its ability to explore new ideas".

The measure of the individual ambidexterity of TTOs was based on previous literature [86]. The measure consisted of eight items, four of them related to individual exploratory orientation. An example of one of these items is: "From your individual perception, indicate to what degree, as a consequence of the COVID-19 pandemic, is each worker in your TTO dedicated to seeking new teachers/researchers to become involved in the performance of the TTO at the national level". The other four items related to individual exploitative orientation. An example of one of these items is: "From their individual perception, to what degree does each worker perform activities that require their accumulated experience". The scales used are shown in Appendix A.

\section{Results}

The identification of groups of TTOs, with homogeneous behaviour and characteristics, was carried out using cluster analysis. This multivariate technique allows it to be determined whether, considering a series of relevant characteristics, it is possible to identify differentiated clusters of TTOs that comply with two main precepts: (i) that each set of TTOs is homogeneous, with respect to the variables used to form the cluster; and, (ii) that the clusters identified present a high degree of differentiation between them. For the cluster analysis, a series of variables were selected for their ability to characterise the cases by associating them with clusters, and for their versatility in adjusting to the particular objectives of cluster analysis [98].

As mentioned above, several responses were obtained from most of the 29 TTOs in the sample. It was therefore necessary to analyse the degree of similarity between the responses obtained from the same TTO, in order to aggregate them.

For this purpose, the Interrater Agreement ratio (rwg) was calculated. The rwg shows whether different respondents from the same organisation agree in their assessments of the exploratory and exploitative orientation, of both the TTO and its members, as well as their academic and market relational capital. The rwg was used to assess the agreement of the two or three respondents from the same TTO, and thus ensure the validity of aggregating responses, in cases where different people from the same company provided similar answers to our questionnaire [99].

The Interrater Agreement ratio, or rwg, was calculated for each of our variables following the procedure established by [100]. As seen in Table 1, in all cases, the rwg shows favourable ratios.

Table 1. Interrater Agreement (rwg).

\begin{tabular}{ccccccccc}
\hline & $\begin{array}{c}\text { Exploratory } \\
\text { Guidance } \\
\text { TTOs }\end{array}$ & $\begin{array}{c}\text { Operational } \\
\text { Guidance } \\
\text { TTOs }\end{array}$ & $\begin{array}{c}\text { Individual } \\
\text { Explorer } \\
\text { Guidance }\end{array}$ & $\begin{array}{c}\text { Individual } \\
\text { Exploitative } \\
\text { Orientation }\end{array}$ & $\begin{array}{c}\text { No. of } \\
\text { Academic } \\
\text { Staff }\end{array}$ & $\begin{array}{c}\text { Frequency of } \\
\text { Academic } \\
\text { Actors }\end{array}$ & $\begin{array}{c}\text { No. of } \\
\text { Market } \\
\text { Actors }\end{array}$ & $\begin{array}{c}\text { Frequency } \\
\text { of Market } \\
\text { Actors }\end{array}$ \\
\hline rwg & 0.9034 & 0.9123 & 0.8991 & 0.9507 & 0.8743 & 0.8858 & 0.9000 & 0.9396 \\
\hline
\end{tabular}


To analyse the ambidextrous orientation of Spanish TTOs and individuals, and the degree of relational capital that these units possess, the hierarchical cluster methodology [101] was applied to identify similar characteristics. The hierarchical cluster methodology is suitable for this research as the number of clusters is not known a priori, our variables are quantitative, and the number of cases, at 29 , is not high [102].

When applying the cluster analysis methodology, several variables were considered that met the requirements of versatility, appropriability and direct relationship between them [103]. These variables were the exploratory and exploitative orientation of the TTOs, the individual exploitative and exploratory orientation, and the academic and market relational capital of these offices. In all cases, the variables were measured using a 5-point Likert scale (1: very low degree and 5: very high degree).

When applying the cluster analysis, Ward's method and the Square Euclidean distance were used. These techniques were frequently used in these studies [102] as they allowed for maximum homogenisation of the clusters. First, it was analysed whether there were two different groups of TTOs, depending on their ambidextrous orientation. As can be seen in the dendogram (Figure 1), two main clusters were identified, one composed of 13 ambidextrous TTOs, and the other containing 16 non-ambidextrous TTOs. Table 2 shows the composition of each of the clusters.

Dendrogram using Ward's Method

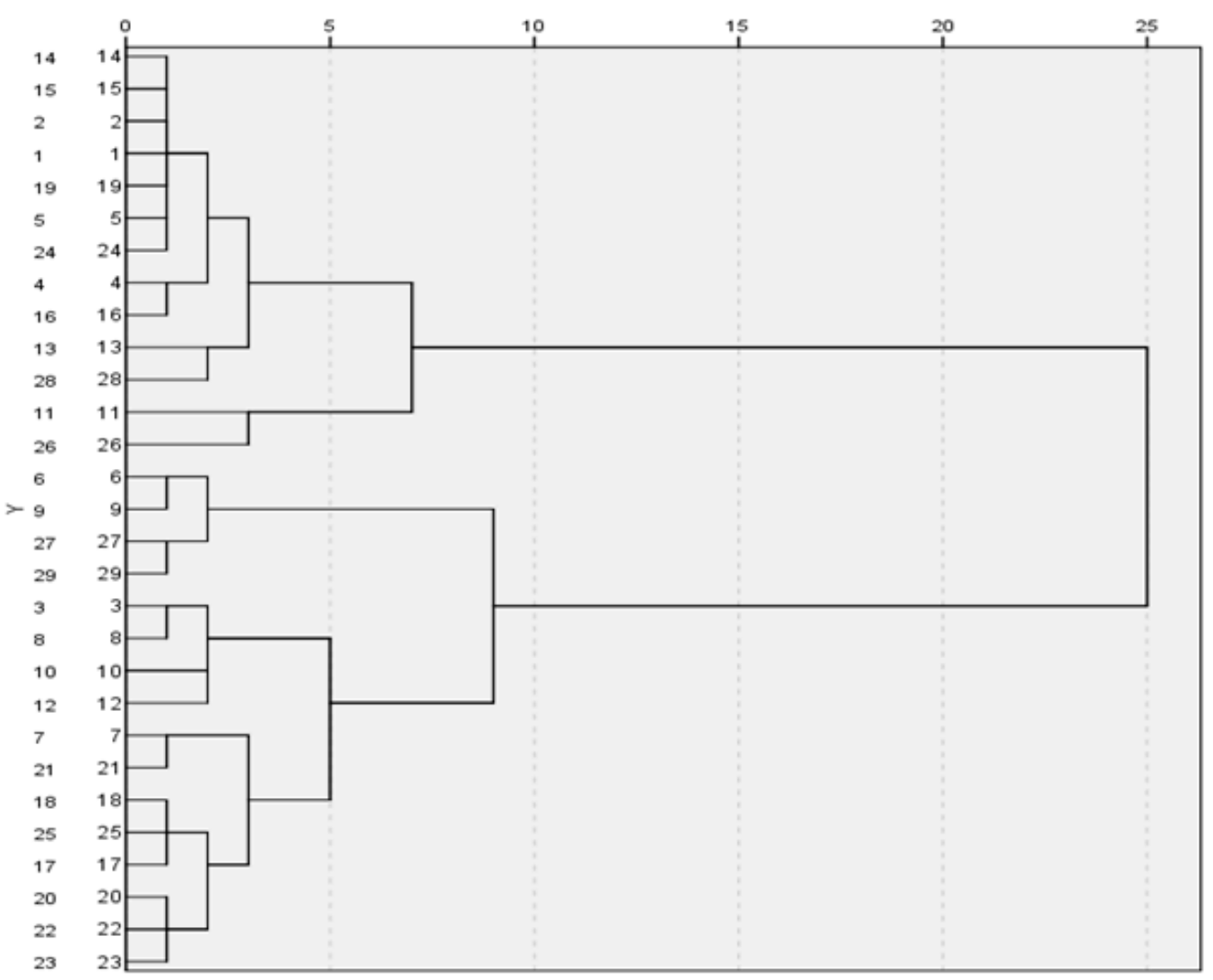

Figure 1. Dendrogram: Ambidextrous orientation of TTOs.

Figure 2 graphically shows the two clusters obtained, as well as the degree of exploratory and exploitative orientation of each TTO and, therefore, their degrees of ambidextrous orientation.

From the above, we can conclude that Hypothesis 1 is partially confirmed, as not all TTOs have ambidextrous orientation.

Next, the same type of analysis was performed, using individual exploratory and exploitative orientation as discriminant variables. The dendogram (Figure 3) shows two 
large clusters composed of 19 TTOs in cluster 1 and 10 TTOs in cluster 2, which refer to TTOs composed of individuals without ambidextrous orientation, and TTOs composed of individuals with ambidextrous orientation, respectively.

Table 2. Ambidextrous orientation clusters of TTOs.

\begin{tabular}{cc}
$\begin{array}{c}\text { Cluster 1: Ambidextrous Orientation of } \\
\text { TTOs }\end{array}$ & $\begin{array}{c}\text { Cluster 2: Non-Ambidextrous Orientation of } \\
\text { TTOs }\end{array}$ \\
\hline University of La Laguna & European University of Madrid \\
\hline University of the Balearic Islands & University of Almeria \\
\hline Carlos III University of Madrid & University of Vigo \\
\hline University of Alicante & University of Santiago de Compostela \\
\hline University of the Basque Country & University of La Coruna \\
\hline Polytechnic University of Valencia & San Antonio Catholic University of Murcia \\
\hline University of Zaragoza & International University of Catalonia \\
\hline University of Cadiz & Pablo de Olavide University \\
\hline Rovira i Virgili University & University of Las Palmas de Gran Canaria \\
\hline University of Cordoba & University of Oviedo \\
\hline Complutense University of Madrid & University of León \\
\hline University of Jaén & Autonomous University of Barcelona \\
\hline Autonomous University of Madrid & National University of Distance Education \\
(UNED)
\end{tabular}

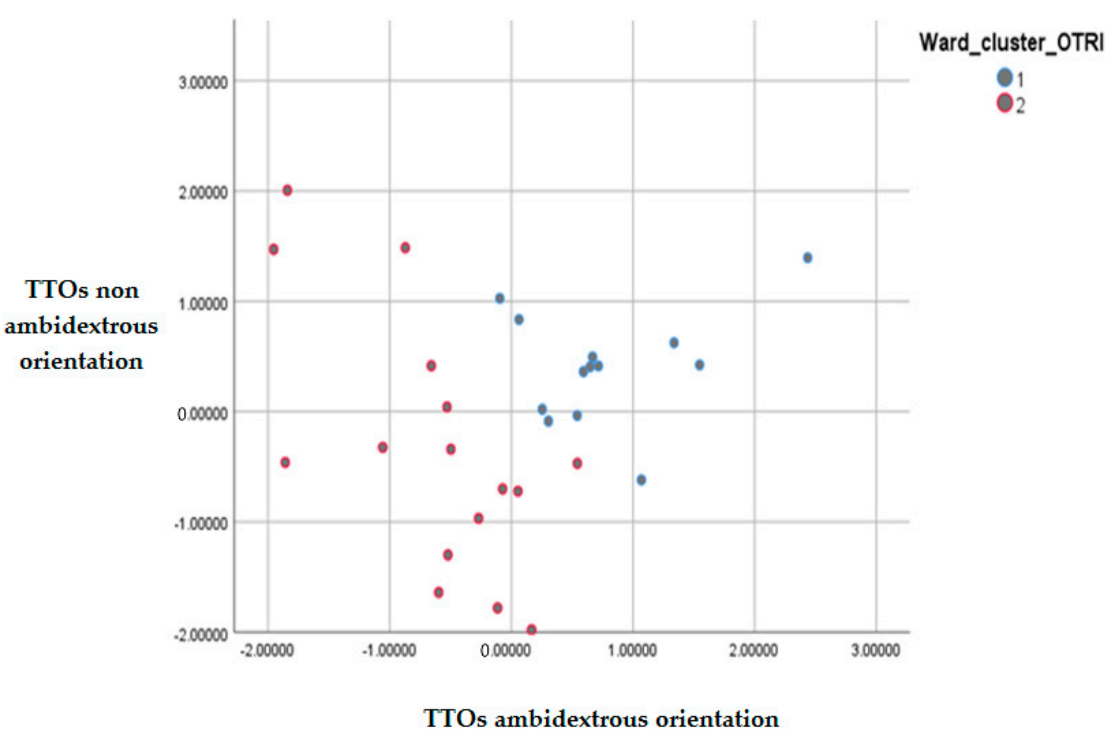

Figure 2. Graphical representation of ambidextrous orientation of clusters of TTOs.

Table 3 shows the composition of these two clusters, and Figure 4 shows the graphical representation of the clusters obtained, as well as the degree of exploratory and exploitative orientation of the individuals, i.e., the degree of ambidexterity of the members of the TTOs.

From this result, it can be concluded that Hypothesis 2 is partially confirmed, as not all TTOs have workers with ambidextrous orientation. 


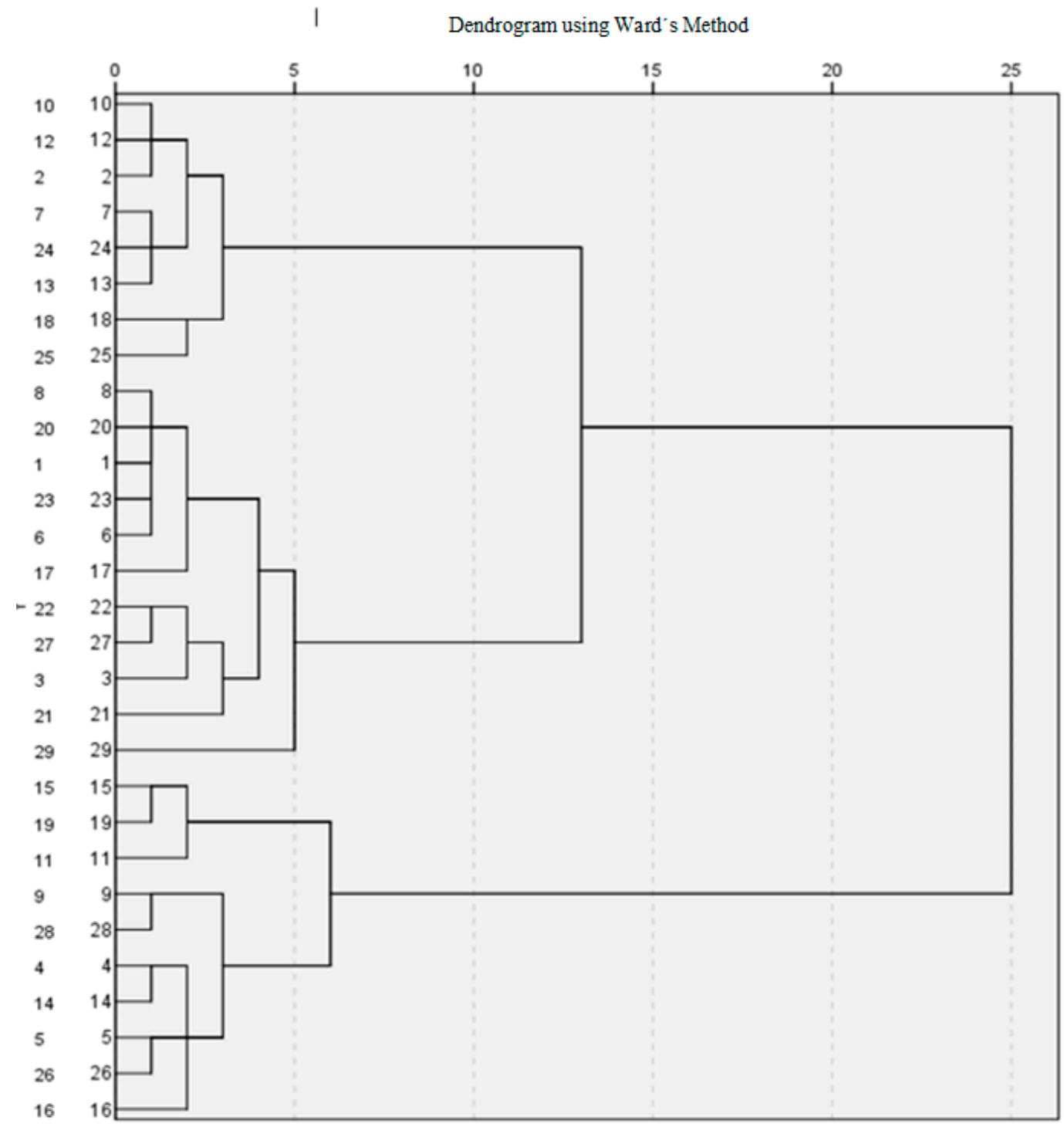

Figure 3. Dendrogram: Individual ambidexterity.

Table 3. Individual ambidexterity clusters.

\begin{tabular}{cc}
\hline $\begin{array}{c}\text { Cluster 1: TTOs with Individuals with No } \\
\text { Ambidextrous Orientation }\end{array}$ & $\begin{array}{c}\text { Cluster 2: TTOs with Ambidextrously } \\
\text { Oriented Individuals }\end{array}$ \\
\hline University of La Laguna & Carlos III University of Madrid \\
\hline University of the Balearic Islands & University of Alicante \\
\hline European University of Madrid & University of La Coruna \\
\hline University of Almeria & University of the Basque Country \\
\hline University of Vigo & University of Zaragoza \\
\hline University of Santiago de Compostela & University of Cadiz \\
\hline San Antonio Catholic University of Murcia & Rovira i Virgili University \\
\hline International University of Catalonia & University of Cordoba \\
\hline Polytechnic University of Valencia & University of Jaén \\
\hline Pablo de Olavide University & Autonomous University of Madrid \\
\hline
\end{tabular}


Table 3. Cont.

\begin{tabular}{cc}
\hline $\begin{array}{c}\text { Cluster 1: TTOs with Individuals with No } \\
\text { Ambidextrous Orientation }\end{array}$ & $\begin{array}{c}\text { Cluster 2: TTOs with Ambidextrously } \\
\text { Oriented Individuals }\end{array}$ \\
\hline University of Las Palmas de Gran Canaria & \\
\hline University of Oviedo \\
\hline University of León \\
\hline Autonomous University of Barcelona \\
\hline Complutense University of Madrid \\
\hline Antonio de Nebrija University \\
\hline University of Huelva \\
\hline Miguel Hernández University
\end{tabular}

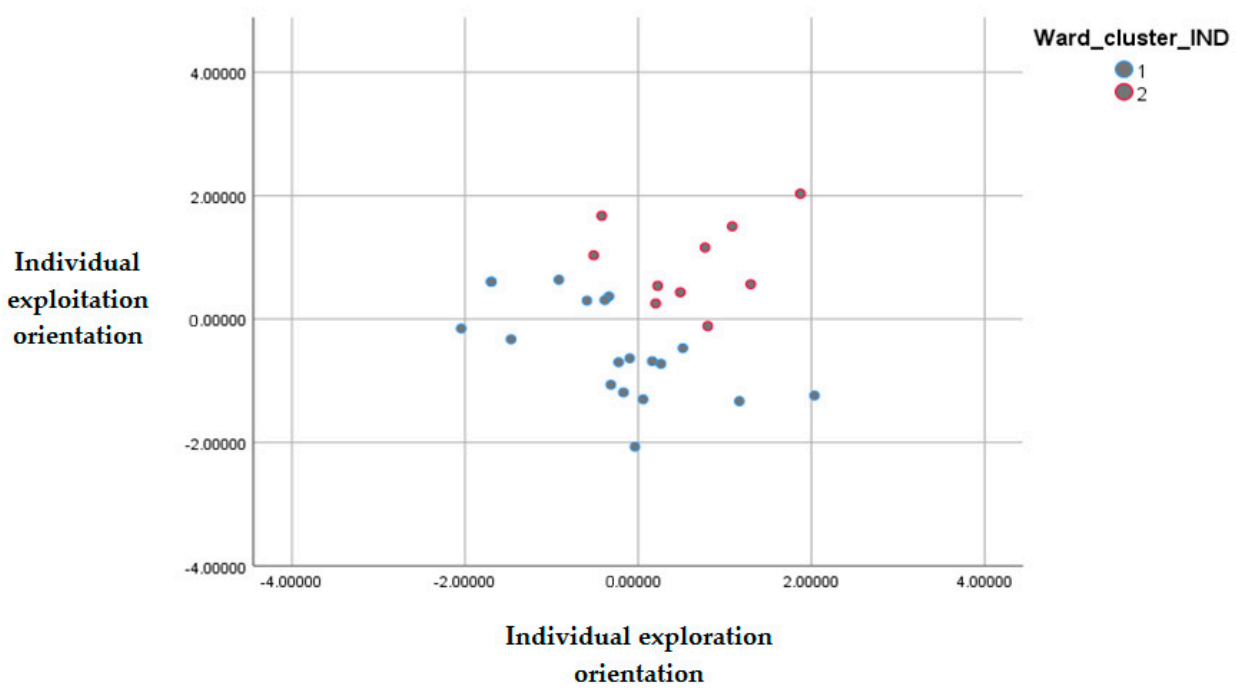

Figure 4. Graphical representation of individual ambidexterity clusters.

Finally, a new cluster analysis was performed with the discriminant variables being the academic and market relational capital of the TTOs. As shown in the dendogram (Figure 5), there are two large sets of TTOs composed of 15 offices with low relational capital in cluster 1, and 14 TTOs with a high relational capital in cluster 2.

Table 4 shows the composition of each of the two clusters identified. Figure 6 shows the graphical representation of the clusters obtained, and the level of development of the TTOs' relational capital.

Finally, we conclude that Hypothesis 3 is partially confirmed, as not all TTOs have developed relational capital. 


\section{Dendrogram using Ward's Method}

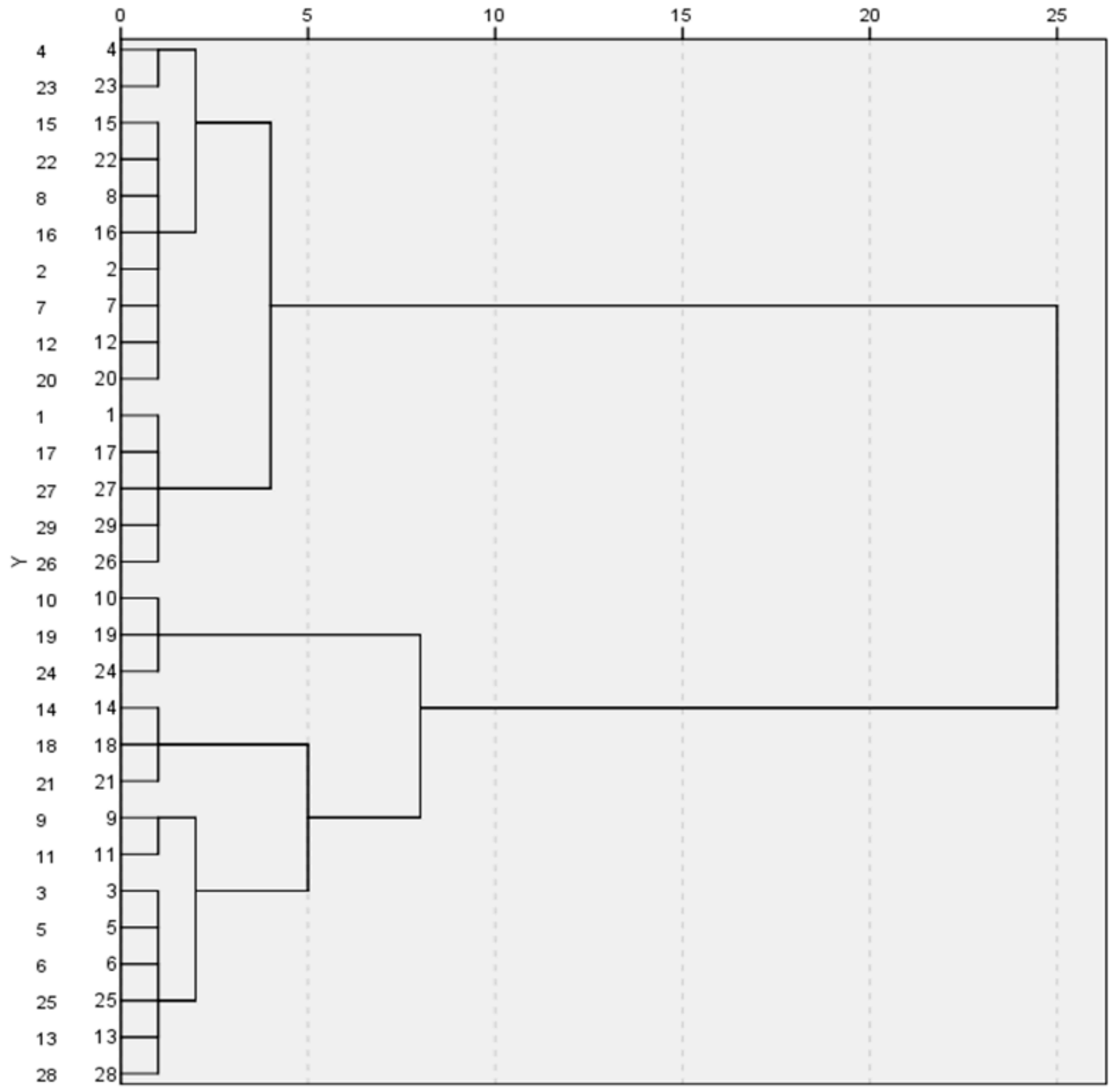

Figure 5. Dendrogram: relational capital.

Table 4. Relational capital clusters.

\begin{tabular}{cc}
\hline Cluster 1: Low Relational Capital & Cluster 2: High Relational Capital \\
\hline University of La Laguna & European University of Madrid \\
\hline University of the Balearic Islands & University of Alicante \\
\hline Carlos III University of Madrid & University of Almeria \\
\hline University of Vigo & University of La Coruña \\
\hline University of Santiago de Compostela & San Antonio Catholic University of Murcia \\
\hline International University of Catalonia & University of the Basque Country \\
\hline
\end{tabular}


Table 4. Cont.

\begin{tabular}{cc}
\hline Cluster 1: Low Relational Capital & Cluster 2: High Relational Capital \\
\hline University of Cadiz & Polytechnic University of Valencia \\
\hline Rovira i Virgili University & University of Zaragoza \\
\hline Pablo de Olavide University & University of Las Palmas de Gran Canaria \\
\hline University of Oviedo & University of Cordoba \\
\hline Autonomous University of Barcelona & University of León \\
\hline National University of Distance Education & Complutense University of Madrid \\
\hline University of Jaén & Antonio de Nebrija University \\
\hline University of Huelva & Autonomous University of Madrid \\
\hline Miguel Hernández University & \\
\hline
\end{tabular}

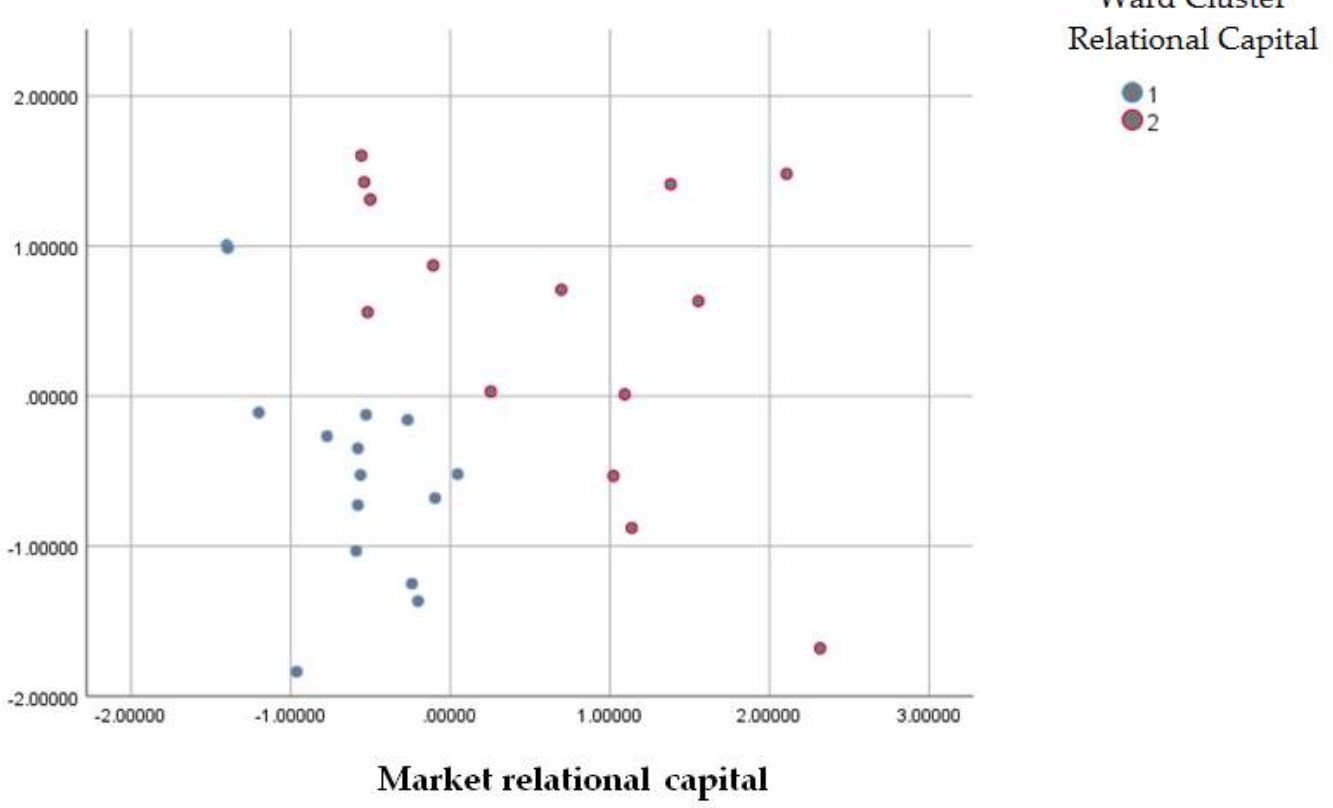

Figure 6. Graphical representation of relational capital clusters.

\section{Discussion and Conclusions}

The literature has shown that ambidexterity and relational capital are two essential characteristics of innovative organisations. Consequently, for TTOs to enhance innovation, they must have an ambidextrous orientation, at both the organisational and individual level, as well as developed academic and market relational capital. Companies that cooperate with TTOs innovate four times more than those that do not co-operate, significantly influencing the implementation of new products [104]. Thus, these offices become key intermediaries for academics, as they support ASOs in their creation and development. They also provide resources and information that could be determinant for the innovation of co-operating companies, so that the innovative efforts of ASOs are closely linked to external sources of knowledge, such as TTOs [22].

Some Spanish ASOs have responded to the changes brought about by the pandemic, with high levels of innovation in their products and services. ASOs from diverse sectors, such as biotechnology, culture and information technology, have taken advantage of the opportunities offered by the new context. The fact that ASOs do not lose their link with their parent company has led us to believe that the reason why some ASOs have responded to these changes, is found in the characteristics of the TTOs with which they have been linked since their creation. Indeed, [105] assume a positive relationship between the existence of 
TTOs and innovation, as business managers and academics often see TTOs as an enabler for the successful commercialization of intellectual property rights.

Four conclusions can be drawn from the obtained results.

Firstly, half of the TTOs surveyed, namely 13 TTOs, had an ambidextrous orientation. This leads us to conclude that just a few of the TTOs are prepared, in this respect, to promote innovation.

Secondly, 10 TTOs were individually ambidextrous, i.e., the employees of these offices were prepared to encourage innovation. Moreover, nine of the offices with individual ambidexterity also had an ambidextrous orientation. Specifically, with the exception of the TTO of the University of Coruña, all of the Spanish TTOs surveyed with an ambidextrous orientation also had individual ambidexterity. The results obtained on the ambidexterity of the TTOs cannot be compared with previous literature, as there were no studies of this type in the context of TTOs. However, other studies, developed in the context of companies, concluded that ambidexterity endowed TTOs with dual structures, and employees with the ability to work towards exploration and exploitation [37-39,46,69,70], resulting in a greater ability to support innovation [40,73,75-80].

Thirdly, from analysing the relational networks of the Spanish TTOs in the study, almost half had high relational capital, despite the opportunities for innovation that these relationships provided, not only to the TTOs themselves, but also to the ASOs. For example, in the current pandemic context, TTOs' relationships with market actors (such as government institutions related to research, e.g., CSIC (Consejo Superior de Investigaciones Científicas-The Spanish National Research Council), CIMCYC (Centro de Investigación Mente, Cerebro y Comportamiento-The Mind, Brain and Behaviour Research Centre) or CITIC (Centro Andaluz de Innovación y Tecnologías de la Información y las Comunicaciones-The Andalusian Centre for Innovation and Information and Communication Technologies), or to public health, such as the Carlos III Institute) would be crucial for the innovation by ASOs. Consequently, as indicated in the literature, having a developed relational capital would be beneficial for enhancing innovation, as the relationships that these units maintain with academics and industry allow for the identification of new innovative opportunities [16,57].

Fourthly, only seven Spanish TTOs, out of the 29 analysed, were found to have an ambidextrous orientation, individual ambidexterity and a high relational capital, in both academic and market actors. Therefore, Spanish TTOs still have a long way to go to become ambidextrous, to develop relational capital that enables innovation, and to provide advice, training, incubation or the provision of various resources to help ASOs take advantage of the innovation opportunities offered by the changes and uncertainty of the current environment.

Several contributions are obtained from this work. Firstly, it deepens the analysis of TTOs, comparing new characteristics of these units, such as ambidexterity, with previous research on size, age and professionalisation. Secondly, this study makes an important contribution to the literature on ambidexterity, in the context of TTOs, where there are no works that analyse the exploratory and exploitative orientation of units, which, by their nature, are destined to exploit university knowledge and identify new markets, customers or uses. Thirdly, this work responds to previous claims that there is a need for more studies to evaluate the importance of these offices, for technology transfers between universities and companies [106]. Fourthly, rather than explaining how TTOs and their characteristics influence the achievement of transfer performance [34], other hitherto overlooked TTO characteristics have been analysed to improve innovation, which are key, above all, for the ASOs created with their advice. Moreover, a contribution is made to the literature on TTO networks in the Spanish context as, although there are works that study the relational networks of TTOs $[22,66]$, there are no studies on relational networks focused on TTOs in Spanish universities.

These findings have practical implications for the management of universities and TTOs, as the results show that not all these offices are ambidextrous and have developed 
relational capital. Therefore, both the exploitative and exploratory orientation of these units, and their employees, as well as the relations of these offices with academic and market actors, should be enhanced.

This study has a limitation that could lead to a future line of research. This limitation, lies in the size of the population of TTOs in Spanish universities, which makes it difficult to apply other statistical techniques, e.g., structural equation modelling with PLS. One possibility, as suggested by [66], is to develop panel data that would allow the study to be extended over several years.

Another future line of research would be to broaden the field of study, by considering samples from other European countries, which would allow us to carry out comparative work. It would also be interesting to make an in-depth analysis of the ASOs that have innovated during the pandemic, and to study whether they have indeed been created and developed under the umbrella of ambidextrous TTOs, and with developed relational capital.

Author Contributions: The authors have contributed to every part of the article in this way. The conceptual part on TTO has been developed by M.F.-A. The conceptual part on Ambidexterity has been developed by T.R.-G. and M.V.-F. Statistical development has been worked on by M.D.-F. Finally, the discussion and conclusions has been developed by M.F.-A., T.R.-G. and M.V.-F. All authors have read and agreed to the published version of the manuscript.

Funding: This work has been co-financed by the 2014-2020 ERDF Operational Programme and by the Department of Economy, Knowledge, Enterprise and Universities of the Regional Government of Andalusia. Project reference: FEDER-UCA18-107689. The translation was made possible with the help of INDESS (University Institute for Sustainable Social Development, of the University of Cadiz).

Institutional Review Board Statement: Not applicable.

Informed Consent Statement: Not applicable.

Data Availability Statement: The data presented in this study are available on request from the corresponding author.

Conflicts of Interest: The authors declare no conflict of interest.

\section{Appendix A}

Regarding ambidextrous orientation, the final measure consisted of 12 items in which respondents were asked to assess their firm's orientation (exploratory and exploitative) using a 5-point scale ranging from 1 (strongly disagree) to 5 (strongly agree). 
Table A1. Ambidextrous Orientation.

\begin{tabular}{|c|c|}
\hline \multicolumn{2}{|c|}{ Ambidextrous Orientation } \\
\hline Exploratory Orientation & Exploitative Orientation \\
\hline $\begin{array}{l}\text { (a) looks for novel technological ideas by } \\
\text { thinking "outside the box" for companies } \\
\text { and/or academic }\end{array}$ & (a) commits to improve quality and lower cost \\
\hline $\begin{array}{c}\text { (b) bases its success on its ability to explore } \\
\text { new technologies }\end{array}$ & $\begin{array}{c}\text { (b) continuously improves the reliability of its } \\
\text { products and services }\end{array}$ \\
\hline $\begin{array}{l}\text { (c) creates products or services that are } \\
\text { innovative to the TTO }\end{array}$ & $\begin{array}{c}\text { (c) constantly surveys existing customers' } \\
\text { satisfaction }\end{array}$ \\
\hline $\begin{array}{l}\text { (d) looks for creative ways to satisfy its } \\
\text { customers' needs (companies and/or } \\
\text { academics) }\end{array}$ & $\begin{array}{c}\text { (d) improves what it offers to keep its current } \\
\text { customers satisfied }\end{array}$ \\
\hline $\begin{array}{l}\text { (e) aggressively ventures into new national } \\
\text { market segments }\end{array}$ & $\begin{array}{l}\text { (e) carries out activities that encourage the use } \\
\text { of services aimed at current customers }\end{array}$ \\
\hline $\begin{array}{l}\text { (f) actively targets new national customer } \\
\text { groups }\end{array}$ & $\begin{array}{c}\text { (f) increases the levels of automation in its } \\
\text { operations }\end{array}$ \\
\hline
\end{tabular}

Regarding individual ambidexterity, the final measure consisted of 8 items in which respondents were asked to assess their individual's orientation (exploratory and exploitative) using a 5-point scale ranging from 1 (strongly disagree) to 5 (strongly agree).

Table A2. Individual Ambidexterity.

\begin{tabular}{|c|c|}
\hline \multicolumn{2}{|c|}{ Individual Ambidexterity } \\
\hline Individual Exploratory Orientation & Individual Exploitative Orientation \\
\hline $\begin{array}{l}\text { (a) search for new academics to be involved in } \\
\text { the performance of the TTO }\end{array}$ & $\begin{array}{l}\text { (a) perform activities where a lot of experience } \\
\text { had been accumulated by them }\end{array}$ \\
\hline $\begin{array}{l}\text { (b) search for new markets, companies, sectors } \\
\text { with which to sign agreements }\end{array}$ & $\begin{array}{l}\text { (b) perform activities which serve existing } \\
\text { customers with existing services/products }\end{array}$ \\
\hline $\begin{array}{l}\text { (c) perform activities requiring some } \\
\text { adaptability on his/her part }\end{array}$ & $\begin{array}{l}\text { (c) perform activities where it is clear to } \\
\text { him/her how to conduct them }\end{array}$ \\
\hline $\begin{array}{l}\text { (d) perform activities requiring him/her to } \\
\text { acquire new skills or knowledge }\end{array}$ & $\begin{array}{l}\text { (d) perform activities primarily focused on } \\
\text { achieving short-term goals }\end{array}$ \\
\hline
\end{tabular}

\section{References}

1. Blankesteijn, M.; Bossink, B.; Van der Sijde, P. Science-based entrepreneurship education as a means for university-industry technology transfer. Int. Entrep. Manag. J. 2021, 17, 779-808. [CrossRef]

2. Vega-Gómez, F.; Miranda-González, F. Choosing between Formal and Informal Technology Transfer Channels: Determining Factors among Spanish Academicians. Sustainability 2021, 13, 2476. [CrossRef]

3. Libecap, G. University Entrepreneurship and Technology Transfer: Process, Design, and Intellectual Property; Elsevier: Amsterdam, The Netherlands, 2005.

4. Algieri, B.; Aquino, A.; Succurro, M. Technology transfer offices and academic spin-off creation: The case of Italy. J. Technol. Transf. 2013, 38, 382-400. [CrossRef]

5. Secundo, G.; De Beer, C.; Passiante, G. Measuring university technology transfer efficiency: A maturity level approach. Meas. Bus. Excell. 2016, 20, 42-54. [CrossRef]

6. Curi, C.; Daraio, C.; Llerena, P. University technology transfer: How (in)efficient are French universities. Camb. J. Econ. 2012, 36, 629-654. [CrossRef]

7. Deiaco, E.; Holmén, M.; McKelvey, M. What does it mean conceptually thatuniversities compete? In Learning to Compete in European Universities: From Social Institution to Knowledge Business; McKelvey, M., Holmén, M., Eds.; Edward Elgar: Cheltenham, UK, 2009; pp. 300-328.

8. Etzkowitz, H.; Webster, A.; Gebbardt, C.; Cantisano Terra, B. The future of the University of the future: Evolution of ivory tower to entrepreneurial paradigm. Res. Policy 2000, 29, 313-330. [CrossRef] 
9. Martin, B. The changing social contract for science and the evolution of the university. In Science and innovation: Rethinking the Rationales for Funding and Governance; Edward Elgar: Cheltenham, UK, 2003; pp. 7-29.

10. Miyata, Y. An empirical analysis of innovative activity of universities in the United States. Technovation 2000, $20,413-425$. [CrossRef]

11. Mustar, P.; Wright, M. Convergence or path dependency in policies to foster the creation ofuniversity spin-off firms? A comparison of France and the United Kingdom. J. Technol. Transf. 2010, 35, 42-65. [CrossRef]

12. Mustar, P.; Wright, M.; Clarysse, B. University spin-off firms: Lessons from ten years of experience in Europe. Sci. Public Policy 2008, 35, 67-80. [CrossRef]

13. Sofía-Olaya, E.; Berbegal-Mirabent, J.; Germán-Duarte, O.G. Performance of university transfer offices as intermediaries for the potentiation of the knowledge market. Intang. Cap. 2014, 10, 155-188.

14. Debackere, K. The TTOs, an organizational innovation to facilitate technology transfer. In University Technology Transfer and Academic Entrepreneurship; World Scientific: Toh Tuck Link, Singapore, 2018; pp. 23-41. [CrossRef]

15. O'Shea, R.; Allen, T.; O'Gorman, C.; Rocher, F. Universities and technology transfer: A review of academic entrepreneurship literature. Ir. J. Manag. 2004, 25, 11-29.

16. Siegel, D.; Waldman, D.; Link, A. Assessing the impact of organizational practices on the relative productivity of university technology transfer offices: An exploratory study. Res. Policy 2003, 32, 27-48. [CrossRef]

17. Caldera, A.; Debande, O. Performance of Spanish universities in technology transfer: An empirical analysis. Res. Policy 2010, 39, 1160-1173. [CrossRef]

18. Friedman, J.; Silberman, J. University technology transfer: Do incentives, management, and location matter. J. Technol. Transf. 2003, 28, 17-30. [CrossRef]

19. Petruzzelli, A.M.; Rotolo, D.; Albino, V. Determinants of patent citations in biotechnology: An analysis of patent influence across the industrial and organizational boundaries. Technol. Forecast. Soc. Chang. 2015, 91, 208-221. [CrossRef]

20. Soto-Acosta, P.; Popa, S.; Palacios-Marques, D. Social web knowledge sharing and innovation performance in knowledge-intensive manufacturing SMEs. J. Technol. Transf. 2017, 42, 425-440. [CrossRef]

21. Lafuente, E.; Berbegal-Mirabent, J. Assessing the productivity of technology transfer offices: An analysis of the relevance of aspiration performance and portfolio complexity. J. Technol. Transf. 2019, 44, 778-801. [CrossRef]

22. Mascarenhas, C.; Marques, C.S.; Galvão, A.R.; Carlucci, D.; Falcão, P.F.; Ferreira, F.A. Analyzing technology transfer offices' influence for entrepreneurial universities in Portugal. Manag. Decis. 2019, 57, 3473-3491. [CrossRef]

23. Holgersson, M.; Aaboen, L. A literature review of intellectual property management in technology transfer offices: From appropriation to utilization. Technol. Soc. 2019, 59, 101132. [CrossRef]

24. Bessant, J.; Rush, H. Building bridges for innovation: The role of consultants in technology transfer. Res. Policy 1995, 24, 97-114. [CrossRef]

25. Siegel, D.S.; Veugelers, R.; Wright, M. Technology transfer offices and commercialization of university intellectual property: Performance and policy implications. Oxf. Rev. Econ. Policy 2007, 23, 640-660. [CrossRef]

26. Fernández-Alles, M.; Ramos, A. The International Potential of Academic Spin-Offs in Spain; UCA: Farnham, UK, 2021.

27. Rasmussen, E.; Wright, M. How can universities facilitate academic spin-offs? An entrepreneurial competency perspective. J. Technol. Transf. 2015, 40, 782-799. [CrossRef]

28. Sinell, A.; Iffländer, V.; Muschner, A. Uncovering transfer-a cross-national comparative analysis. Eur. J. Innov. Manag. 2018, 21, 70-95. [CrossRef]

29. Gorączkowska, J. Enterprise innovation in technology incubators and university business incubators in the context of Polish industry. Oeconomia Copernic. 2020, 11, 799-817. [CrossRef]

30. Clarysse, B.; Tartari, V.; Salter, A. The impact of entrepreneurial capacity, experience and organizational support on academic entrepreneurship. Res. Policy 2011, 40, 1084-1093. [CrossRef]

31. Hülsbeck, M.; Lehmann, E.E.; Starnecker, A. Performance of technology transfer offices in Germany. J. Technol. Transf. 2013, 38, 199-215. [CrossRef]

32. O'Shea, R.P.; Allen, T.J.; Chevalier, A.; Roche, F. Entrepreneurial orientation, technology transfer and spin-off performance of U.S. Universities. Res. Policy 2005, 34, 994-1009. [CrossRef]

33. Powers, J.; McDougall, P. University start-up formation and technology licensing with firms that go publics: A resource-based view of academic entrepreneurship. J. Bus. Ventur. 2005, 20, 291-311. [CrossRef]

34. Ustundag, A.; Ugurlu, S.; Serdar, M. Evaluating the performance of technology transfer offices. J. Enterp. Inf. 2011, 24, 322-337. [CrossRef]

35. Muscio, A. What drives the university use of technology transfer offices? Evidence from Italy. J. Technol. Transf. 2010, 35, 181-202. [CrossRef]

36. Huyghe, A.; Knockaert, M. The influence of organizational culture and climate on entrepreneurial intentions among research scientists. J. Technol. Transf. 2015, 40, 138-160. [CrossRef]

37. Ambos, T.C.; Makela, K.; Birkinshaw, J.; D’Este, P. When does university research get commercialized? Creating ambidexterity in research institutions. J. Manag. Stud. 2008, 45, 1424-1447. [CrossRef]

38. Chang, Y.C.; Yang, P.Y.; Chen, M.H. The determinants of academic research commercial performance: Towards an organizational ambidexterity perspective. Res. Policy 2009, 38, 936-946. [CrossRef] 
39. Chang, Y.C.; Yang, P.Y.; Martin, B.R.; Chi, H.R. Entrepreneurial universities and research ambidexterity: A multilevel analysis. Technovation 2016, 54, 7-21. [CrossRef]

40. Tushman, M.; Smith, W.K.; Wood, R.C.; Westerman, G.; O'Reilly, C. Organizational designs and innovation streams. Ind. Corp. Chang. 2010, 19, 1331-1366. [CrossRef]

41. O'Reilly, C.A.; Tushman, M.L. Ambidexterity as a dynamic capability: Resolving the innovator's dilemma. Res. Organ. Behav. 2008, 28, 185-206. [CrossRef]

42. Raisch, S.; Birkinshaw, J. Organizational ambidexterity: Antecedents, outcomes, and moderators. J. Manag. 2008, 34, 375-409. [CrossRef]

43. Benner, M.J.; Tushman, M.L. Exploitation, exploration, and process management: The productivity dilemma revisited. Acad. Manag. Rev. 2003, 28, 238-256. [CrossRef]

44. Siggelkow, N.; Levinthal, D.A. Temporarily divide to conquer: Centralized, decentralized, and reintegrated organizational approaches to exploration and adaptation. Organ. Sci. 2003, 14, 650-669. [CrossRef]

45. Raisch, S.; Birkinshaw, J.; Probst, G.; Tushman, M.L. Organizational ambidexterity: Balancing exploitation and exploration for sustained performance. Organ. Sci. 2009, 20, 685-695. [CrossRef]

46. Lubatkin, M.H.; Simsek, Z.; Ling, Y.; Veiga, J.F. Ambidexterity and performance in small-to medium-Sized firms: The pivotal role of top management team behavioral integration. J. Manag. 2006, 32, 646-672. [CrossRef]

47. Carey, S.; Lawson, B.; Krause, D.R. Social capital configuration, legal bonds and performance in buyer-supplier relationships. J. Oper. Manag. 2011, 29, 277-288. [CrossRef]

48. Tsai, W.; Ghoshal, S. Social capital and value creation: The role of intrafirm networks. Acad. Manag. J. 1998, 41, 464-476.

49. Yayla, S.; Yeniyurt, S.; Uslay, C.; Cavusgil, E. The role of market orientation, relational capital, and internationalization speed in foreign market exit and re-entry decisions under turbulent conditions. Int. Bus. Rev. 2018, 27, 1105-1115. [CrossRef]

50. Fernández-Alles, M.; Diánez-González, J.P.; Rodríguez-González, T.; Villanueva-Flores, M. TTOs characteristics and university entrepreneurship: A cluster analysis. J. Sci. Technol. Policy Manag. 2019, 10, 61-889. [CrossRef]

51. Jensen, R.A.; Thursby, M.C. Patent licensing and the research university (No. w10758). Natl. Bur. Econ. Res. 2004. [CrossRef]

52. Siegel, D.S.; Phan, P. Analyzing the effectiveness of university technology transfer: Implications for entrepreneurship education. In Advances in the Study of Entrepreneurship, Innovation, and Economic Growth; Emerald Group Publishing Limited: Bingley, UK, 2005; Volume 16, pp. 1-38.

53. Kenney, M.; Patton, D. Reconsidering the Bayh-Dole Act and the current university invention ownership model. Res. Policy 2009, 38, 1407-1422. [CrossRef]

54. Lockett, A.; Siegel, D.; Wright, M.; Ensley, M.D. The creation of spin-off firms at public research institutions: Managerial and policy implications. Res. Policy 2005, 34, 981-993. [CrossRef]

55. Krueger, N.F.; Cummings, B.; Nichols, S.P. From Bureaucratic Tech Transfer to Entrepreneurial Tech Commercialization. Available online: https:/ / papers.ssrn.com/sol3/papers.cfm?abstract_id=1288942 (accessed on 3 June 2021).

56. Markman, G.; Phan, P.; Balkin, D.; Gianiodis, P. Entrepreneurship and university-based technology transfer. J. Bus. Ventur. 2005, 20, 241-263. [CrossRef]

57. Padilla-Meléndez, A.; Garrido-Moreno, A. Open innovation in universities: What motivates researchers to engage in knowledge transfer exchanges? Int. J. Entrep. Behav. Res. 2012, 18, 417-439. [CrossRef]

58. Secundo, G.; De Beer, C.; Fai, F.M.; Schutte, C.S. Increasing university entrepreneurialism: Qualitative insights from the technology transfer office. Meas. Bus. Excell. 2019, 23, 253-268. [CrossRef]

59. De la Puente, F.; Martínez, C.; Equiza, S.; Mata, F.J. OTRI: Entre la Relación y el Mercado; Newbook Ediciones: Pamplona, Spain, 2000.

60. Lambert, R. Lambert Review of Business-university Collaboration: Final Report. Available online: https://globalhighered.files. wordpress.com/2009/09/lambert_review_2003.pdf (accessed on 3 June 2021).

61. Clarysse, B.; Wright, M.; Lockett, A.; Van de Velde, E.; Vohora, A. Spinning out new ventures: A typology of incubation strategies from European research institutions. J. Bus. Ventur. 2005, 20, 183-216. [CrossRef]

62. Lockett, A.; Siegel, D.; Wright, M.; Franklin, S. Technology transfer and universities' spin-out strategies. Small Bus. Econ. 2003, 20, 185-200. [CrossRef]

63. Lockett, A.; Wright, M. Resources, capabilities, risk capital and the creation of university spin-out companies. Res. Policy 2005, 34, 1043-1057. [CrossRef]

64. McAdam, M.; McAdam, R. High tech start-ups in University Science Park incubatiors: The relationship between the start-up's lifecycle profession and use of the incubator's resources. Technovation 2008, 28, 277-290. [CrossRef]

65. Mosey, S.; Wright, M. From human capital to social capital: A longitudinal study of technology based academic entrepreneurs. Entrep. Theory Pract. 2007, 31, 909-935. [CrossRef]

66. Rodeiro, D.; Fernández, S.; Otero, L.; Rodríguez, A. Determining factors in the creation of university spin-offs. Eur. J. Manag. Bus. Econ. 2010, 19, 47-68.

67. Siegel, D.; Waldman, D.; Atwater, L.; Link, A. Toward a model of the effective transfer of scientific knowledge from academician stopractitioners: Qualitative evidence from the commercialization of university technologies. J. Eng. Technol. Manag. 2004, 21, 115-142. [CrossRef] 
68. Vohora, A.; Wright, M.; Lockett, A. Critical junctures in the development of university high-tech spinout companies. Res. Policy 2004, 33, 147-175. [CrossRef]

69. O'Reilly, C.A.; Tushman, M.L. The ambidextrous organisation. Harv. Bus. Rev. 2004, 82, 74-84.

70. Tushman, M.L.; O’Reilly, C.A. Ambidextrous organisations-managing evolutionary and revolutionary change. Calif. Manag. Rev. 1996, 38, 8-30. [CrossRef]

71. Floyd, S.W.; Lane, P.J. Strategizing throughout the organization: Managing role conflict in strategic renewal. Acad. Manag. Rev. 2000, 25, 154-177. [CrossRef]

72. Adler, P.; Goldoftas, B.; Levine, D. Flexibility versus efficiency? A case study of model changeovers in the Toyota production system. Organ. Sci. 1999, 10, 43-68. [CrossRef]

73. Burgers, J.H.; Jansen, J.J.P.; Van den Bosch, F.A.J.; Volberda, H.W. Structural differentiation and corporate venturing: The moderating role of formal and informal integration mechanisms. J. Bus. Ventur. 2009, 24, 206-220. [CrossRef]

74. Eisenhardt, K.M.; Tabrizi, B.N. Accelerating adaptive processes: Product innovation in the global computer industry. Adm. Sci. Q. 1995, 40, 84-110. [CrossRef]

75. Katila, R.; Ahuja, G. Something old, something new: A longitudinal study of search behavior and new product introduction. Acad. Manag. J. 2002, 45, 1183-1194.

76. McGrath, R. Exploratory learning, innovative capacity, and managerial oversight. Acad. Manag. J. 2001, 44, 118-131.

77. Phene, A.; Tallman, S.; Almeida, P. When do acquisitions facilitate technological exploration and exploitation? J. Manag. 2012, 38, 753-783. [CrossRef]

78. Rothaermel, F.T.; Deeds, D.L. Exploration and exploitation alliances in biotechnology: A system of new product development. Strateg. Manag. J. 2004, 25, 201-221. [CrossRef]

79. Sarkees, M.; Hulland, J. Innovation and efficiency: It is possible to have it all. Bus. Horiz. 2009, 52, 45-55. [CrossRef]

80. Yang, H.; Atuahene-Gima, K. Ambidexterity in Product Innovation Management: The Direct and Contingent Effects on Product Development Performance. Available online: https:/ /www.researchgate.net/publication/303321328_Pro-innovation_culture_ ambidexterity_and_new_product_development_performance_Polynomial_regression_and_response_surface_analysis (accessed on 3 June 2021).

81. O'Reilly, C.A.; Tushman, M.L. Organizational ambidexterity: Past, present, and future. Acad. Manag. Perspect. 2013, 27, 324-338. [CrossRef]

82. Van Looy, B.; Landoni, P.; Callaert, J.; Van Pottelsberghe, B.; Sapsalis, E.; Debackere, K. Entrepreneurial effectiveness of European universities: An empirical assessment of antecedents and trade-offs. Res. Policy 2011, 40, 553-564. [CrossRef]

83. O'Shea, R.; Hugh, H.; Allen, T. Determinants and consequences of university spinoff activity: A conceptual framework. J. Technol. Transf. 2008, 33, 653-666. [CrossRef]

84. Stuart, T.E.; Ding, W.W. When do scientists become entrepreneurs? The social structural antecedents of commercial activity in the academic life sciences. Am. J. Sociol. 2006, 112, 97-144. [CrossRef] [PubMed]

85. Thursby, J.; Kemp, S. Growth and productive efficiency of university intellectual property licensing. Res. Policy 2002, 31, 109-124. [CrossRef]

86. Bonesso, S.; Gerli, F.; Scapolan, A. The individual side of ambidexterity: Do individuals' perceptions match actual behaviours in reconciling the exploration and exploitation trade-off? Eur. Manag. J. 2014, 32, 392-405. [CrossRef]

87. Levinthal, D.A.; March, J.G. The myopia of learning. Strateg. Manag. J. 1993, 14, 95-112. [CrossRef]

88. Mom, T.J.; Van Den Bosch, F.A.; Volberda, H.W. Understanding variation in managers' ambidexterity: Investigating direct and interaction effects of formal structural and personal coordination mechanisms. Organ. Sci. 2009, 20, 812-828. [CrossRef]

89. Xiang, S.; Chen, G.; Liu, W.; Zhou, Q.; Xing, S. An empirical study of the impact of goal orientation on individual ambidexteritymoderating roles of goal interdependence and constructive controversy. Nankai Bus. Rev. Int. 2019, 10, 465-484. [CrossRef]

90. Gibson, C.B.; Birkinshaw, J. The antecedents, consequences, and mediating role of organizational ambidexterity. Acad. Manag. J. 2004, 47, 209-226.

91. Hoang, H.; Antoncic, B. Network-based research in entrepreneurship: A critical review. J. Bus. Ventur. 2003, 18, 165-187. [CrossRef]

92. Lechner, C.; Dowling, M.; Welpe, I. Firm networks and firm development: The role of the relational mix. J. Bus. Ventur. 2006, 21, 514-540. [CrossRef]

93. Bojica, A.M.; Arroyo, M.R.; Fuentes, M.D.M.F. Knowledge acquisition through interorganizational relationships and entrepreneurial orientation: The mediating role of second-order social capital. Cuad. Econ. Dir. Empresa 2012, 15, 141-153.

94. Fernández-Alles, M.; Camelo-Ordaz, C.; Franco-Leal, N. Key sources and actors for the evolution of academic spin-offs. J. Technol. Transf. 2015, 40, 976-1002. [CrossRef]

95. Timmons, J.A.; Spinelli, S. New Venture Creation; McGraw Hill Higher Education: Boston, MA, USA, 2004.

96. Gübeli, M.H.; Doloreux, D. An empirical study of university spin-off development. Eur. J. Innov. Manag. 2005, 8, 269-282. [CrossRef]

97. Bjørnåli, E.S.; Gulbrandsen, M. Exploring board formation and evolution of board composition in academic spin-offs. J. Technol. Transf. 2010, 35, 92-112. [CrossRef]

98. Iglesias-Sánchez, P.P.; Jambrino Maldonado, C.; Peñafiel Velasco, A. Caracterizacion de las spin-off universitarias como mecanismo de transferencia de tecnología a través de un análisis clúster. Rev. Eur. Dir. Econ. Empresa 2013, 21, 240-254. [CrossRef] 
99. Kozlowski, S.W.J.; Hattrup, K. A Disagreement About Within-Group Agreement: Disentangling Issues of Consistency Versus Consensus. J. Appl. Psychol. 1992, 77, 161-167. [CrossRef]

100. James, L.R.; Demaree, R.G.; Wolf, G. rwg: An assessment of within-group interrater agreement. J. Appl. Psychol. 1993, 78, 306-309. [CrossRef]

101. Everitt, B.S.; Landau, S.; Leese, M.; Stahl, D. Cluster Analysis; Wiley: Chichester, UK, 2011.

102. Pérez-Lopez, C. Técnicas Estadísticas Multivariantes Con SPSS; Garceta ed: Madrid, Spain, 2009.

103. Cesaroni, F.; Piccaluga, A. The activities of university knowledge transfer offices: Towards the third mission in Italy. J. Technol. Transf. 2016, 41, 753-777. [CrossRef]

104. Goraczkowska, J.; Tomaszewski, M. Support of innovation activity in small and medium-sized enterprises in the Greater Poland Voivodeship. Ekon. Prawo. Econ. Law 2019, 18, 183-195. [CrossRef]

105. Barra, C.; Zotti, R. The contribution of university, private and public sector resources to Italian regional innovation system (in) efficiency. J. Technol. Transf. 2018, 43, 432-457. [CrossRef]

106. Stankeviciènè, J.; Kraujalienè, L.; Vaiciukevičiūtè, A. Assessment of technology transfer office performance for value creation in higher education institutions. J. Bus. Econ. Manag. 2017, 18, 1063-1081. [CrossRef] 